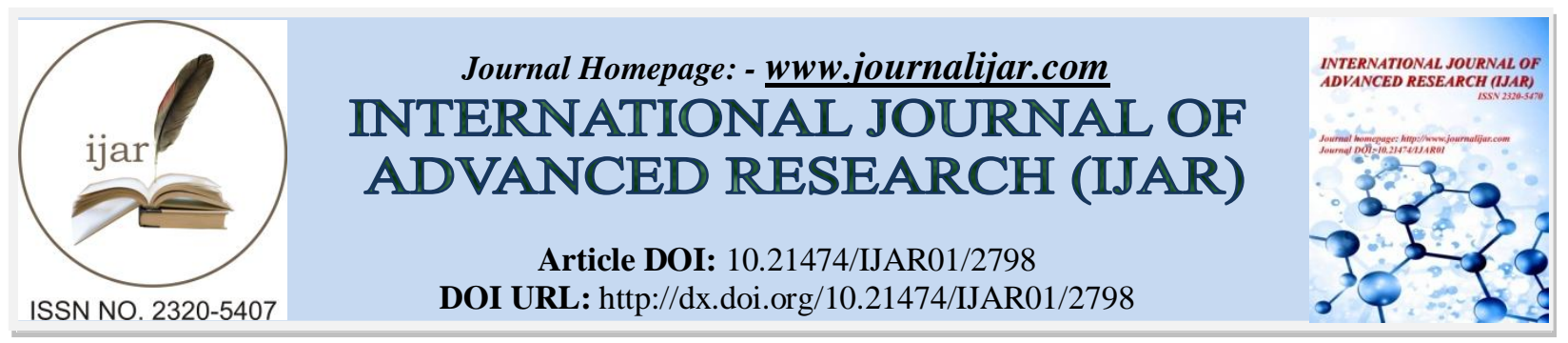

RESEARCH ARTICLE

\title{
IMPACT OF ECONOMIC REFORMS IN EXPENDITURE PATTERN OF TAMIL NADU
}

\author{
G. Mahalakshmi and Dr. C. Ramesh.
}

1. Associate Professor of Economics, Rani Anna Govt. College (W), Tirunelveli-8.

2. Associate Professor of Economics, Aditanar College of Arts and Science, Tiruchendur.

\section{Manuscript Info}

Manuscript History

Received: 15 November 2016

Final Accepted: 17 December 2016

Published: January 2017

Key words:-

Public Expenditure, Pre Reform, Post Reform, Compound Annual Growth Rate, Income Elasticity.

\section{Abstract}

India is described as a union of states and the bulk of responsibility for social and economic development lies with the state governments. It is accepted that it is the duty of the state governments to ensure that every citizen can enjoy the primary necessities of life proportionate with need. Therefore state government expenditure is an important instrument for the protection and promotion of socio-economic welfare of the people. An important issue which has gained prominence in the recent years is the impact of economic reforms on the expenditure pattern of state governments. The core of this study is to analyze the pattern of public expenditure in Tamil Nadu during pre and post reform period in order to understand the impact of economic reforms on that.

Copy Right, IJAR, 2016,. All rights reserved.

\section{Introduction:-}

Public expenditure is the sum of all types of expenses incurred by the government of a country and its authorized agencies during the period of one financial or accounting year. Only in the beginning of the $20^{\text {th }}$ century it was realised that public expenditure was far more important in its implications and bearing on public welfare than public revenue. The main reason for the early neglect of the subject of public expenditure seems to be that the amount of public expenditure was very small as the field of governmental activity was restricted. In recent times, public expenditure has increased enormously. The main reason is that the functions of the state have increased manifold. Unlike the past when the state was considered as a 'police state', now the state is regarded as a welfare state which is concerned with promoting the welfare of its citizens.

In India, public expenditure has increasing year by year due to the expansion of state activities. In the sphere of development most of the functions and responsibilities pertain to State Governments. For a due discharge of this wide array of functions, State Governments have perforce to spend more and ever more. Therefore state governments face an explosive cycle of current expenditure growth and are in the throes of a debt trap in recent years.

Mathur K.P.L analysed fiscal reforms and public expenditure management in state governments of India and found that the reduction in total expenditure to GDP ratio from 16.37 per cent in 1985-90 to 15.44 per cent in 1995-2000 is only because of a reduction in capital expenditure to GDP from 3.21 per cent to 2.11 per cent. The increases in interest payment and pensions have been at the cost of capital expenditure of the state governments. While analyzing the state finances during the period 1985-86 to 2001-02, Narasimhulu stated that the problems of the Central

Corresponding Author:- G. Mahalakshmi.

Address:- Associate Professor of Economics, Rani Anna Govt. College (W), Tirunelveli-8. 
government are reflected at the level of States since the framework of fiscal federalism within which India functions makes Centre-State resource flows an important component of State budgets.

The core of this study is to analyze the pattern of revenue and capital expenditure in Tamil Nadu during the pre and post reform period to understand the impact of economic reforms on that. Therefore, this study is related with the following special problems. Have the expenditure on revenue account been affected during the post reform period? Whether economic reform compresses capital expenditure of Tamil Nadu? Is there any growth in the volume of expenditure after removing the adverse effect of rise in population and price level? How far revenue and capital expenditure are responsive to the growth of the economy during pre and post reform period?

\section{Objectives:-}

1. To compare the growth pattern of revenue expenditure in Tamil Nadu during the pre and post reform period.

2. To estimate the growth pattern of capital expenditure in Tamil Nadu during the pre and post reform period.

\section{Hypotheses:-}

1. There is no significant difference between pre and post reform period in the growth pattern of revenue expenditure.

2. Economic reforms do not have the impact of curtailment oncapital expenditure in Tamil Nadu.

\section{Nature and Sources of Data:-}

Secondary data form the basis of this study. The data on expenditure for the years from 1971-72 to 2013-14 were collected from RBI Bulletins and RBI Website. The data on Net State Domestic Product was collected from Economic Surveys and Hand Book of Statistics on Indian Economy.

\section{Methodology:-}

Expenditure devoted per head of population was calculated to eliminate the influence of population change. Compound Annual Growth Rate was used to estimate the growth rate of expenditure in Tamil Nadu during the pre and post reform period. The functional form used to estimate the compound growth rate is $Y=a b^{t .}$ To assess the growth of public expenditure in real terms, the influence of price changes should be eliminated and for this national income deflator at 1980-81 prices has been made use of. To trace the income elasticity of state expenditures in revenue and capital account, regression coefficient was calculated by employing the following formula: $\log \mathrm{Y}=\mathrm{a}+$ $\mathrm{b} \log \mathrm{X}$

\section{Results and Discussion:-}

Public expenditure in India is generally divided for accounting purposes into two broad categories, namely, expenditures on revenue account and capital account. Revenue Expenditures are those that are routine, recurring and periodical with no enduring value beyond the financial year in which they are incurred. Capital expenditures are those that are spent on assets from which income is generated. These are normally enduring in nature.

Table 1 :- Revenue Expenditure of Tamil Nadu - Pre Reform

\begin{tabular}{|c|c|c|c|c|c|c|}
\hline \multirow[t]{2}{*}{ Year } & \multicolumn{2}{|c|}{ Current Price } & \multicolumn{2}{|c|}{ Constant Price } & \multirow[t]{2}{*}{$\%$ to $\mathrm{TE}$} & \multirow[t]{2}{*}{$\%$ to NSDP } \\
\hline & $\mathbf{A E}$ & $\mathbf{P E}$ & $\mathbf{A E}$ & PE & & \\
\hline 1971-72 & 357.36 & 86.74 & 769.28 & 186.72 & 90.97 & 13.25 \\
\hline $1972-73$ & 417.03 & 99.48 & 811.56 & 193.60 & 92.17 & 14.69 \\
\hline 1973-74 & 472.63 & 110.84 & 783.69 & 183.79 & 93.32 & 13.77 \\
\hline $1974-75$ & 528.36 & 121.85 & 754.55 & 174.01 & 93.04 & 14.52 \\
\hline 1975-76 & 557.92 & 126.56 & 827.52 & 187.72 & 89.14 & 14.99 \\
\hline 1976-77 & 628.36 & 140.25 & 874.49 & 195.18 & 91.91 & 14.60 \\
\hline $1977-78$ & 706.12 & 155.11 & 923.67 & 202.89 & 94.57 & 14.99 \\
\hline 1978-79 & 753.51 & 162.94 & 970.41 & 209.84 & 92.81 & 15.00 \\
\hline $1979-80$ & 849.55 & 180.89 & 949.67 & 202.20 & 92.63 & 13.94 \\
\hline $1980-81$ & 1152.25 & 241.63 & 1152.25 & 241.63 & 93.13 & 15.96 \\
\hline 1981-82 & 1359.89 & 280.92 & 1233.19 & 254.75 & 90.45 & 15.67 \\
\hline $1982-83$ & 1576.08 & 320.65 & 1318.78 & 268.30 & 91.27 & 17.87 \\
\hline 1983-84 & 1910.80 & 382.94 & 1472.75 & 295.15 & 91.28 & 18.69 \\
\hline
\end{tabular}




\begin{tabular}{|l|l|l|l|l|l|l|}
\hline $1984-85$ & 2210.34 & 436.45 & 1578.55 & 311.70 & 93.03 & 18.38 \\
\hline $1985-86$ & 2449.75 & 476.71 & 1637.83 & 318.72 & 94.14 & 17.90 \\
\hline $1986-87$ & 2775.70 & 532.42 & 1735.83 & 332.96 & 94.26 & 18.14 \\
\hline $1987-88$ & 3374.81 & 638.22 & 1927.18 & 364.45 & 94.95 & 18.58 \\
\hline $1988-89$ & 3763.04 & 701.75 & 1991.15 & 371.32 & 95.19 & 18.43 \\
\hline $1989-90$ & 4730.79 & 870.13 & 2312.22 & 425.28 & 95.68 & 19.77 \\
\hline $1990-91$ & 5641.29 & 1023.57 & 2486.57 & 451.17 & 96.21 & 20.38 \\
\hline CAGR & $\mathbf{1 5 . 6 0}$ & $\mathbf{1 3 . 8 8}$ & $\mathbf{6 . 0 4}$ & $\mathbf{4 . 5 1}$ & & \\
\hline
\end{tabular}

Source: AE at Current Price- RBI Bulletins and RBI Website; PE, AE \& PE at Constant Price, \% to AE, \% to NSDP, Regression Co-efficient - Computed.

Note: AE - Absolute Expenditure, PE- Per capita Expenditure, TE- Total Expenditure( Revenue and Capital Expenditure), NSDP - Net State Domestic Product

From 1971-72 to 1990-91, there was a striking increase in total expenditure on revenue account in money terms. It rose from Rs.357.36 crores in 1971-72 to Rs.5641.29 crores in 1990-91, thus registered growth by nearly 16 per cent within a period of 20 years. In per capita term, the expenditure increased by 14 per cent from Rs.86.74 in 1971-72 to Rs.1023.57 in 1990-91. At constant price, the compound annual growth rate for total and per capita expenditure was 6.04 and 4.51 per cent respectively.

In 1971-72, revenue expenditure as a proportion of total expenditure claimed 90.97 per cent of total expenditure. In 1990-91, it increased to 96.21 percent. The share of revenue expenditure in net state domestic product had also increased from 13.25 per cent to 20.38 per cent prior to economic reforms.

Table 2 :- Revenue Expenditure of Tamil Nadu - Post Reform

\begin{tabular}{|c|c|c|c|c|c|c|}
\hline \multirow[t]{2}{*}{ Year } & \multicolumn{2}{|c|}{ Current Price } & \multicolumn{2}{|c|}{ Constant Price } & \multirow[t]{2}{*}{ \% to TE } & \multirow[t]{2}{*}{ \% to NSDP } \\
\hline & $\mathbf{A E}$ & $\mathbf{P E}$ & $\mathbf{A E}$ & $\mathbf{P E}$ & & \\
\hline $1991-92$ & 8679.52 & 1553.83 & 3375.24 & 604.24 & 96.88 & 26.64 \\
\hline 1992-93 & 8542.53 & 1511.59 & 3051.94 & 540.03 & 96.36 & 22.53 \\
\hline 1993-94 & 8758.00 & 1531.97 & 2835.99 & 496.08 & 94.09 & 16.96 \\
\hline 1994-95 & 9634.95 & 1666.28 & 2838.97 & 490.98 & 93.41 & 15.72 \\
\hline 1995-96 & 10910.57 & 1865.76 & 2941.25 & 502.97 & 94.86 & 15.65 \\
\hline 1996-97 & 13064.89 & 2209.43 & 3266.51 & 552.41 & 93.42 & 16.51 \\
\hline $1997-98$ & 14950.85 & 2500.68 & 3504.87 & 586.22 & 91.06 & 16.13 \\
\hline 1998-99 & 17697.40 & 2928.00 & 3822.23 & 632.38 & 93.88 & 16.74 \\
\hline 1999-2000 & 20727.83 & 3392.63 & 4359.02 & 713.46 & 96.98 & 17.32 \\
\hline $2000-01$ & 21752.44 & 3522.59 & 4427.92 & 717.06 & 93.36 & 16.68 \\
\hline 2001-02 & 21556.97 & 3454.31 & 4255.39 & 681.89 & 92.38 & 16.41 \\
\hline 2002-03 & 25687.70 & 4053.01 & 4875.94 & 769.33 & 94.04 & 18.58 \\
\hline 2003-04 & 25270.94 & 3926.95 & 4625.86 & 718.83 & 87.56 & 16.42 \\
\hline $2004-05$ & 29154.87 & 4462.99 & 5040.90 & 771.65 & 86.46 & 15.06 \\
\hline 2005-06 & 32008.67 & 4827.91 & 5306.77 & 800.43 & 88.76 & 13.99 \\
\hline 2006-07 & 38264.97 & 5688.06 & 5950.60 & 884.55 & 86.54 & 13.83 \\
\hline 2007-08 & 42975.01 & 6297.09 & 6291.22 & 921.85 & 85.20 & 13.69 \\
\hline 2008-09 & 53590.26 & 7742.12 & 7215.79 & 1042.46 & 85.48 & 14.91 \\
\hline $2009-10$ & 59375.35 & 8458.94 & 7525.14 & 1072.07 & 87.38 & 13.81 \\
\hline $2010-11$ & 72916.30 & 10245.99 & 8449.17 & 1187.25 & 85.43 & 13.81 \\
\hline 2011-12 & 83838.04 & 11621.74 & 8918.94 & 1236.35 & 83.69 & 13.91 \\
\hline 2012-13 & 97067.44 & 13276.49 & 10596.88 & 1449.40 & 86.95 & 14.45 \\
\hline $2013-14$ & 109824.7 & 14824.02 & 12175.68 & 1643.46 & 86.48 & 14.23 \\
\hline CAGR & 12.52 & 11.07 & 6.4 & 5.02 & & \\
\hline \multicolumn{3}{|c|}{ REGRESSION CO-EFFICIENT } & & & & \\
\hline
\end{tabular}


Source: AE at Current Price- RBI Bulletins and RBI Website; PE, AE \& PE at Constant Price, $\%$ to TE, $\%$ to NSDP and Regression Co-efficient - Computed.

During the post-reform period, the total expenditure increased far less rapidly by comparison. The total expenditure which amounted to Rs.8679.52 crores in 1991-92, went up to Rs.109824.67 crores in 2013-14, that is, a growth by 12.52 per cent in a period of 23 years. In 1991-92, per capita expenditure was Rs. 1553.83 and it increased to Rs. 14824.02 in 2013-14. Hence, per capita expenditure increased by 11 per cent during the post-reform period.

In 1991-92, the proportion of revenue expenditure to total expenditure was at the level of 96.88 per cent. The share was more than 90 per cent till 2002-03. After that, it formed 85 to 89 per cent of total expenditure. Likewise the share of revenue expenditure has declined from 26.64 per cent to 14.23 per cent after reforms in Tamil Nadu.

It could be ascertained that the growth rate of total and per capita revenue expenditure was less during the postreform period when compared with pre-reform period. A considerable fall in the proportion of revenue expenditure to total expenditure was noticed in the post reform period. Besides there was a significant decline in the proportion of total expenditure to state domestic product during the post reform period. Moreover prior to economic reforms, one per cent increase in per capita income led to 1.15 per cent increase in per capita expenditure, but after reforms, one per cent increase in per capita income has ruled to only 0.91 per cent increase in per capita expenditure. Hence, our first hypothesis, there is no significant difference between pre and post reform period in the growth pattern of revenue expenditure in Tamil Nadu is disproved.

It is contradictory to the findings of the study made by Seema Joshi(2006) which shows that fiscal adjustments in India during the reform period have been brought about by reducing public investment (i.e, capital expenditure) rather than by revenue expenditure. Anil Kumar Jain (2010) also found that, in India, government expenditure has tilted in favour of revenue expenditure and capital expenditure had to bear the brunt. In the words of Ashok K.Lahiri, "one of the most striking features of Indian public finances at the sub national level has been the crowding out of capital and other essential expenditures including developmental and maintenance expenditures - by increasing revenue expenditure mainly owing to higher interest payment and wages".

Table 3:- Capital Expenditure of Tamil Nadu - Pre Reform

\begin{tabular}{|l|l|l|l|l|l|l|}
\hline \multirow{2}{*}{ Year } & Current Price & \multicolumn{2}{l}{ Constant Price } & \multirow{2}{*}{ \% to TE } & \multirow{2}{*}{ \% to NSDP } \\
\cline { 2 - 6 } & $\mathbf{A E}$ & $\mathbf{P E}$ & $\mathbf{A E}$ & $\mathbf{P E}$ & & \\
\hline $1971-72$ & 35.46 & 8.61 & 76.33 & 18.53 & 9.03 & 1.32 \\
\hline $1972-73$ & 35.42 & 8.45 & 68.93 & 16.44 & 7.83 & 1.25 \\
\hline $1973-74$ & 33.82 & 7.93 & 56.08 & 13.15 & 6.68 & 0.99 \\
\hline $1974-75$ & 39.55 & 9.12 & 56.48 & 13.03 & 6.96 & 1.09 \\
\hline $1975-76$ & 67.97 & 15.42 & 100.82 & 22.87 & 10.86 & 1.83 \\
\hline $1976-77$ & 55.31 & 12.35 & 76.98 & 17.18 & 8.09 & 1.29 \\
\hline $1977-78$ & 40.53 & 8.90 & 53.02 & 11.65 & 5.43 & 0.86 \\
\hline $1978-79$ & 58.34 & 12.62 & 75.13 & 16.25 & 7.19 & 1.16 \\
\hline $1979-80$ & 67.59 & 14.39 & 75.56 & 16.09 & 7.37 & 1.11 \\
\hline $1980-81$ & 85.06 & 17.84 & 85.06 & 17.84 & 6.87 & 1.18 \\
\hline $1981-82$ & 143.53 & 29.65 & 130.16 & 26.89 & 9.55 & 1.65 \\
\hline $1982-83$ & 150.75 & 30.67 & 126.14 & 25.66 & 8.73 & 1.71 \\
\hline $1983-84$ & 182.51 & 36.58 & 140.67 & 28.19 & 8.72 & 1.79 \\
\hline $1984-85$ & 165.64 & 32.71 & 118.29 & 23.36 & 6.97 & 1.38 \\
\hline $1985-86$ & 152.48 & 29.67 & 101.94 & 19.84 & 5.86 & 1.11 \\
\hline $1986-87$ & 168.96 & 32.41 & 105.66 & 20.27 & 5.74 & 1.10 \\
\hline $1987-88$ & 179.54 & 33.95 & 102.53 & 19.39 & 5.05 & 0.99 \\
\hline $1988-89$ & 190.29 & 35.49 & 100.69 & 18.78 & 4.81 & 0.93 \\
\hline $1989-90$ & 213.35 & 39.24 & 104.28 & 19.18 & 4.32 & 0.89 \\
\hline $1990-91$ & 222.49 & 40.37 & 98.07 & 17.79 & 3.79 & 0.80 \\
\hline CAGR & $\mathbf{1 1 . 8 5}$ & $\mathbf{1 0 . 0 8}$ & $\mathbf{3 . 2 5}$ & $\mathbf{1 . 6 1}$ & & \\
\hline REGRESSION CO-EFFICIENT & & $\mathbf{0 . 8 9}$ & & & \\
\hline
\end{tabular}


Source: AE at Current Price- RBI Bulletins and RBI Website; PE, AE \& PE at Constant Price, \% to TE, \% to NSDP and Regression Co-efficient - Computed.

The total capital outlay increased from Rs.35.46 crores in 1971-72 to Rs.222.49 crores in 1990-91 and registered 11.85 percent growth. In per capita terms, it was Rs.8.61 in 1971-72. But it enlarged to Rs.40.37 in 1990-91 after a chequered growth in between 1971-72 and 1990-91. The compound annual growth rate was 10.08 percent. At constant price, the growth rate registered by total outlay was 3.25 percent. But per capita expenditure fell down from Rs.18.53 to 17.79 which accounted for 1.61 percent change. Capital outlay as a proportion of total expenditure in 1971-72 claimed 9.03 percent. But in 1990-91, it declined to 3.79 percent. The share was the maximum of 10.86 per cent in 1975-76. The percentage share of capital expenditure to net state domestic product also decelerated. In 197172, the share was 1.32 per cent and in 1990-91, it dipped to 0.80 per cent. "Since 1970s Tamil Nadu has opted for large current expenditure at the expense of capital outlays"(M.S.Guhan 1979). The present study supported this.

Table 4:- Capital Expenditure of Tamil Nadu - Post Reform

\begin{tabular}{|c|c|c|c|c|c|c|}
\hline \multirow{2}{*}{ Year } & \multicolumn{2}{|c|}{ Current Price } & \multicolumn{2}{|c|}{ Constant Price } & \multirow[b]{2}{*}{$\%$ to TE } & \multirow[b]{2}{*}{ \% to NSDP } \\
\hline & $\mathbf{A E}$ & $\mathbf{P E}$ & $\mathbf{A E}$ & $\mathbf{P E}$ & & \\
\hline $1991-92$ & 279.09 & 49.96 & 108.53 & 19.43 & 3.12 & 0.86 \\
\hline 1992-93 & 322.37 & 57.04 & 115.17 & 20.38 & 3.64 & 0.85 \\
\hline 1993-94 & 550.52 & 96.30 & 178.27 & 31.18 & 5.91 & 1.07 \\
\hline 1994-95 & 679.95 & 117.59 & 200.35 & 34.65 & 6.59 & 1.11 \\
\hline $1995-96$ & 590.94 & 101.05 & 159.30 & 27.24 & 5.14 & 0.85 \\
\hline 1996-97 & 919.64 & 155.52 & 229.93 & 38.88 & 6.58 & 1.16 \\
\hline $\begin{array}{l}1997-98 \\
\end{array}$ & 1467.79 & 245.50 & 344.09 & 57.55 & 8.94 & 1.58 \\
\hline 1998-99 & 1153.32 & 190.81 & 249.09 & 41.21 & 6.12 & 1.09 \\
\hline 1999-2000 & 644.93 & 105.56 & 135.63 & 22.20 & 3.02 & 0.54 \\
\hline $2000-01$ & 1546.88 & 250.50 & 314.88 & 50.99 & 6.64 & 1.19 \\
\hline 2001-02 & 1777.91 & 284.89 & 350.96 & 56.24 & 7.62 & 1.35 \\
\hline 2002-03 & 1627.54 & 256.79 & 308.93 & 48.74 & 5.96 & 1.18 \\
\hline 2003-04 & 3589.90 & 557.85 & 657.13 & 102.11 & 12.44 & 2.33 \\
\hline 2004-05 & 4563.97 & 698.65 & 789.11 & 120.80 & 13.54 & 2.36 \\
\hline 2005-06 & 4054.56 & 611.55 & 672.21 & 101.39 & 11.24 & 1.77 \\
\hline 2006-07 & 5952.37 & 884.81 & 925.66 & 137.60 & 13.46 & 2.15 \\
\hline 2007-08 & 7462.23 & 1093.43 & 1092.41 & 160.07 & 14.80 & 2.38 \\
\hline 2008-09 & 9104.30 & 1315.29 & 1225.87 & 177.10 & 14.52 & 2.53 \\
\hline $2009-10$ & 8572.59 & 1221.30 & \begin{tabular}{|c|}
1086.48 \\
\end{tabular} & 154.79 & 12.62 & 1.99 \\
\hline 2010-11 & 12436.27 & 1747.51 & 1441.40 & 202.54 & 14.57 & 2.36 \\
\hline $2011-12$ & 16335.65 & 2264.47 & \begin{tabular}{|l|}
1737.84 \\
\end{tabular} & 240.90 & 16.31 & 2.71 \\
\hline $2012-13$ & 14567.68 & 1992.51 & 1590.36 & 217.52 & 13.05 & 2.17 \\
\hline 2013-14 & 17173.07 & 2318.00 & 1903.89 & 256.98 & 13.52 & 2.23 \\
\hline CAGR & 20.92 & 19.36 & \begin{tabular}{|l|}
14.34 \\
\end{tabular} & 12.86 & & \\
\hline \multicolumn{3}{|c|}{ REGRESSION CO-EFFICIENT : } & 1.39 & & & \\
\hline
\end{tabular}

Source: AE at Current Price- RBI Bulletins and RBI Website; PE, AE \& PE at Constant Price, \% to TE, \% to NSDP and Regression Co-efficient - Computed.

During the post reform period, the total capital outlay shot up tremendously from Rs.279.09 crores to Rs.17173.07 crores which accounted 20.92 percent growth rate. Per capita expenditure also surged voluminously from Rs.49.96 to Rs.2318.00 and registered 19.36 percent growth rate during the same period. At constant price also, growth rate of total and per capita capital outlay was high during the post reform period.

Regarding the percentage share of capital outlay to total expenditure, it moved up largely. In 1991-92, it was only 3.12 percent. But in 2013-14, it jumped to 13.52 percent. The percentage share of capital expenditure to net state domestic product also accelerated. In 1991-92, the share was only 0.86 per cent. But in 2013-14, it has augmented to 2.23 per cent. It is inferred from the analysis that growth rate of capital outlay during post reform period is very much higher than pre reform period. Besides, the share of capital outlay in total expenditure is increased in post reform period against pre reform period. The regression co-efficient representing the income elasticity of capital 
expenditure implies that the increase in per capita income by one per cent has led to an increase in the per capita capital outlay by 1.39 per cent in the pot reform period, but it was 0.89 in the pre reform period.

C.Rangarajan stated that "Over the last several years the proportion of capital expenditures to the total has shown a sharp decline. For the Central Government this proportion has declined from 24 per cent in 1992-93 to 15 per cent in 2000-2001". "Capital expenditure was expanded at a lower rate and hence capital expenditure as percentage of NSDP dipped to 3.33 in 1997-98 from 5.01 in 1990-91 in Gujarat. This indicates that the reduction in fiscal deficit was achieved by compressing capital expenditure"(Atul Sarma). Various studies show that economic reforms have the impact of compressing capital expenditure in India and the states.( Seeta Prabhu 1994, Mahendra Dev 2000, Mathur 2001, Manoj Dolli 2012).

The result of the study undertaken by Jegadish Gandhi deviated from this opinion. It revealed that Tamil Nadu did not opt for reductions in their capital outlays. The Gross Fiscal Deficit of Tamil Nadu has increased for Rs.8,548 crores in 2008-09 to Rs. 16,880 crores in 2011-12. The capital outlay increased by 57.3 per cent for Rs.9,104 crores to Rs.15,880 crores in the same period. The present study endorses the same view and disregards the general opinion that economic reforms compress the capital expenditure in order to reduce fiscal deficit. So, it is inferred that, as far as, the state Tamil Nadu is concerned, economic reform does not have adverse impact on the capital outlay. Hence the second hypothesis "Economic reforms do not have the impact of curtailment on capital expenditure in Tamil Nadu" is proved.

\section{Conclusion:-}

The present study exhibits that in Tamil Nadu total public expenditure is reduced because of the reduction of revenue expenditure. And there is no adverse impact on the capital expenditure. The study suggested that reduction of fiscal deficit should not be done at the cost of bringing down the public expenditure. States may take efforts to collect more revenue from non-tax sources for reducing fiscal deficit. The government should increase the expenditures well enough to counter balance the impact of price rise and increase in population.

\section{References:-}

1. Ashok K.Lahiri, (2000) "Sub National Public Finance in India", Economic and Political Weekly, Vol.XXXV, No.18, April 29, p.1543.

2. Atul Sarma(2000), "Gujarat Finances: Reform of Budgetary Management", Economic and Political Weekly, Aug26-Sep2, pp.3125-3136

3. Guhan ,M.S.(1979), State Finances in Tamil Nadu, Madras Institute for Developmental Studies, Madras, p.259.

4. Jegadish Gandhi,P. (2013), "Socio- Economy of Tamil Nadu : An Overview", Tamil Nadu Economy Issue, December 15, p.29

5. Mahendra Dev,(2000), "Economic Reforms, Poverty, Income Distribution and Employment", Economic and Political Weekly, Vol.35, No.10(Mar 4-10), pp.823-835.

6. Manoj Dolli(2012), "Trends and Growth of Public Expenditure in India During 2001-12, International Journal of Research in Commerce, Economics and Management, Vol.2, No.4, April, pp.55-56.

7. Mathur, K.P.L.(2001), “India: Fiscal Reforms and Public Expenditure Management”, JBIC Research Paper No.11, Sep, pp.70-71

8. Narasimhulu.M., "State Finances In India - An Analysis", Southern Economist, Vol.41, No.9, September1, 2002. Pp.5-7

9. Rangarajan,C.(2001), "Better Expenditure Management will Accelerate Growth", Southern Economist, Vol.40, No.60, July 15, P.10

10. Seema Joshi(2006), “Impact of Economic Reforms on Social Sector Expenditure in India”, Economic and Political Weekly, Jan 28, pp.359-360.

11. Seeta Prabhu, K. (1994), "Structural Adjustment with a Human Face”, Economic and Political Weekly, April 16-23, p.1021

12. RBI Bulletin - Various Issues

13. Economic Survey - Various Surveys

14. Hand Book of Statistics on Indian Economy - Various Issues.

15. RBI Website 